Русак Олена Петрівна кандидат економічних наук, доцент, доцент кафедри аналізу і статистики ім. І.В. Поповича, Поліський національний університет, Старий бульвар, 7, м. Житомир, 10002, тел.: (0412) 47-03-19, e-mail: erusak1208@gmail.com, https://orcid.org/0000-0001-5509-0515

Довженко Валентина Анатоліївна кандидат економічних наук, доцент, доцент кафедри економічної теорії, інтелектуальної власності та публічного управління, Поліський національний університет, Старий бульвар, 7, м. Житомир, 10002, тел.: (0412) 47-03-19, e-mail: vdovzhenko@ukr.net, https://orcid.org/00000001-7441-3535

Золотницька Юлія Вікторівна кандидат економічних наук, доцент, доцент кафедри економічної теорії, інтелектуальної власності та публічного управління, Поліський національний університет, Старий бульвар, 7, м. Житомир, 10002, тел.: (0412) 47-03-19, e-mail: zolotyuliya @ukr.net, https://orcid.org/0000-0002-9278-0707

\title{
СТАТИСТИКО-АНАЛІТИЧНІ ІНСТРУМЕНТИ ТА АУДИТ В ПУБЛІЧНОМУ УПРАВЛІННІ
}

Анотація. Глобальні проблеми сучасності $\epsilon$ наслідками проведення політичних реформ, результати яких не завжди були виправданими з точки зору нерівномірності між соціально-економічними, науково-технічними та публічними індикаторами розвитку країни. Такі проблеми мають характер комплексності та всеосяжності, тобто вони тісно взаємопов'язані як на регіональному так і національному рівнях. Відповідно до цього, набуває актуальності процес формування інституції публічного управління, діяльність якої направлена на задоволення потреб та інтересів соціуму, стаючи основним регулятором взаємовідносин між публічною адміністрацією, суб'єктами (органами й посадовими особами) виконавчої влади та місцевого самоврядування й громадянами.

Однак такі дії не можуть бути виправданими без використання статистикоаналітичних інструментів, які здатні в режимі реального часу представляти результати оперативної обробки великих масивів доступних даних з виділенням цінної інформації щодо прийняття управлінських рішень. В контексті проведення оцінки результативності та ефективності публічного управління вагомого 
значення набуває аудит, який відіграє соціально-регулятивну роль в умовах становлення громадянського суспільства та активізує процес запровадження інноваційних методів діяльності органів публічної влади.

Зазначено, що для налагодження ефективної роботи сфери публічного управління необхідно використовувати низку статистико-аналітичних методів i прийомів які б дозволили провести якісний моніторинг дотичних суб'єктів до даної гілки правління. 3-поміж найбільш вживаних методів, виділено наступні: абсолютні та відносні показники, зведення і групування даних, середні величини та показники варіації, ряди динаміки, дисперсійний аналіз, кореляційнорегресійний аналіз, кластерний аналіз тощо.

Доведено, що вагоме значення має політична аналітика, оскільки вона досліджує процеси розроблення та реалізації державно-владних рішень, задовольняє потреби, насамперед, суб'єктів державної влади, які несуть відповідальність за їі збереження та примноження. Для інших же зацікавлених сторін аналіз публічної політики висвітлює процес реалізації державної влади та створює можливості для опосередкованої участі в цьому процесі.

Ключові слова. Статистика, аналітика, аудит, публічне управління, суб’єкти виконавчої влади, місцеве самоврядування, громадянами.

Rusak Olena Petrivna $\mathrm{PhD}$ in Economics, Associate professor Associate professor of the department of Analysis and Statistics named after I. Popovych, Polissia National University, Staryi Boul., 7, Zhytomyr, 10002, tel.: (0412) 47-03-19, e-mail: erusak1208@gmail.com, https://orcid.org/0000-0001-5509-0515, https//orcid:00000001-5509-0515

Dovzhenko Valentina Anatoliyivna $\mathrm{PhD}$ in Economics, Associate Professor of the Department of Economic Theory, Intellectual Property and Public Administration, Polissia National University, Staryi Boul., 7, Zhytomyr, 10002, tel.: (0412) 47-03-19, e-mail: vdovzhenko@ukr.net, https://orcid.org/0000-0001-7441-3535

Zolotnytska Yuliya Viktorivna PhD in Economics, Associate Professor of the Department of Economic Theory, Intellectual Property and Public Administration, Polissia National University, Staryi Boul., 7, Zhytomyr, 10002, tel.: (0412) 47-03-19, e-mail: zolotyuliya@ukr.net, https://orcid.org/0000-0002-9278-0707

\section{STATISTICAL AND ANALYTICAL INSTRUMENTS AND AUDIT IN PUBLIC GOVERNANCE}

Abstract. The global problems of today are the consequences of political reforms, the results of which have not always been justified in terms of inequality between socio- 
economic, scientific, technical and public indicators of the country's development. Such problems are complex and comprehensive, meaning that they are closely interlinked at both the regional and national levels. Accordingly, the process of forming a public administration institution, whose activities are aimed at meeting the needs and interests of society, becoming the main regulator of relations between public administration, entities (bodies and officials) of executive power and local government and citizens.

However, such actions cannot be justified without the use of statistical and analytical tools that are able to present in real time the results of operational processing of large arrays of available data with the allocation of valuable information on management decisions. In the context of assessing the effectiveness and efficiency of public administration is also important audit, which plays a socio-regulatory role in the formation of civil society and intensifies the process of introducing innovative methods of public authorities.

It is noted that in order to establish the effective work of public administration it is necessary to use a number of statistical and analytical methods and techniques that would allow for quality monitoring of the entities involved in this branch of government. Among the most commonly used methods are the following: absolute and relative indicators, summary and grouping of data, averages and indicators of variation, time series, analysis of variance, correlation-regression analysis, cluster analysis and more.

It is proved that political analytics is important because it examines the processes of development and implementation of government decisions, meets the needs of, first of all, the subjects of state power, which are responsible for its preservation and increase. For other stakeholders, public policy analysis highlights the process of exercising state power and creates opportunities for indirect participation in this process.

Keywords: statistics, analytics, audit, public administration, executive bodies, local self-government, citizens.

Постановка проблеми. Сучасні реформації в Україні характеризуються своєю складністю і багатогранністю, мають тривалий характер і проявляються у всіх сферах суспільного життя. Публічне управління не $\epsilon$ виключенням, адже всі зміни, які там відбуваються, зумовлені низкою важливих завдань орієнтованих на забезпечення належної якості управління, як на рівні політичного керівництва, так і на рівні публічного управління та адміністрування. Однак такі дії не можуть бути виправданими без використання статистико-аналітичних інструментів, які здатні в режимі реального часу представляти результати оперативної обробки великих масивів доступних даних з виділенням цінної інформації щодо прийняття управлінських рішень. В контексті проведення оцінки результативності та 
ефективності публічного управління вагомого значення також набуває аудит, який відіграє соціально-регулятивну роль в умовах становлення громадянського суспільства та активізує процес запровадження інноваційних методів діяльності органів публічної влади. Ефективне використання сукупності зазначених інструментів сприятиме модернізації і побудові системи дієвого та прозорого публічного управління здатної відповідати на усі виклики сьогодення.

Аналіз останніх досліджень i публікацій. Сучасний методичний інструментарій дослідження основних аспектів формування публічного управління висвітлено в наукових працях М. Андріснка, П. Гамана [2], О. Чальцева [9], А. Грабченка, В. Федоровича, Я. Гаращенка [3], А. Мармози [7], Т. Іванової [5], Н. Обушної [8]. Однак в умовах сьогодення виникає необхідність у деталізації статистико-аналітичних інструментів та аудиту, які б дозволили провести якісний моніторинг даної сфери 3 метою підвищення ефективності прийняття управлінських рішень.

Метою статті $\epsilon$ обгрунтування статистико-аналітичних інструментів та аудиту в публічному управлінні.

Виклад основного матеріалу. Публічне управління в умовах сьогодення являє собою систему взаємодіючих норм, ідей та державних (політичних) інститутів, орієнтованих на ефективну організацію політичної влади як на центральному так і місцевому рівнях управління, створення дієвої системи місцевого самоврядування. Головним завданням таких дій $\epsilon$ максимальне наближення i виконання потреб і запитів населення, налагодження тісного взаємозв'язку між громадянами та державою. Важливість та необхідність використання статистико-аналітичних інструментів i аудиту в публічному управлінні обумовлено рядом важливих завдань, вирішення яких дозволяє запобігти прорахункам і помилкам в державно-управлінській діяльності, уникнути не бажаних соціально-політичних наслідків. До таких слід віднести:

- діагностика соціально-регулятивної ролі публічного управління;

- дослідження рівня професійної підготовки управлінських кадрів вищої ланки нової генерації;

- порівняльна оцінка ефективності та результативності роботи органів місцевого самоврядування;

- дослідження соціально-економічного розвитку регіонів та ОТГ;

- об'єктивне вивчення результатів управління і відповідність їх суспільним потребам та інтересам;

- проведення аудиту щодо ефективності та результативності управлінських рішень, відповідальності та підзвітності органів публічної влади суспільству, тощо.

3 огляду на вагомість зазначених питань, статистико-аналітичні інструменти 
є своєрідною інтерпретацією інформації щодо економічних, соціальних, демографічних, екологічних явищ і процесів, які в повному обсязі відображають механізм публічного управління (рис. 1). Під впливом нормативно-правового та інформаційного забезпечення, політична складова даного механізму в першу чергу взаємодіє 3 аналітикою. В іiі основу закладена теоретична складова, що передбачає виявлення взаємозалежностей між суб'єктами публічного процесу, його закономірностей, аналогів і детермінант. Поряд із теоретичною, не менш важливе значення має емпірична складова, дослідження якої направлене на спостереження, порівняння, експеримент, вимірювання та моніторинг даних в публічному управлінні.

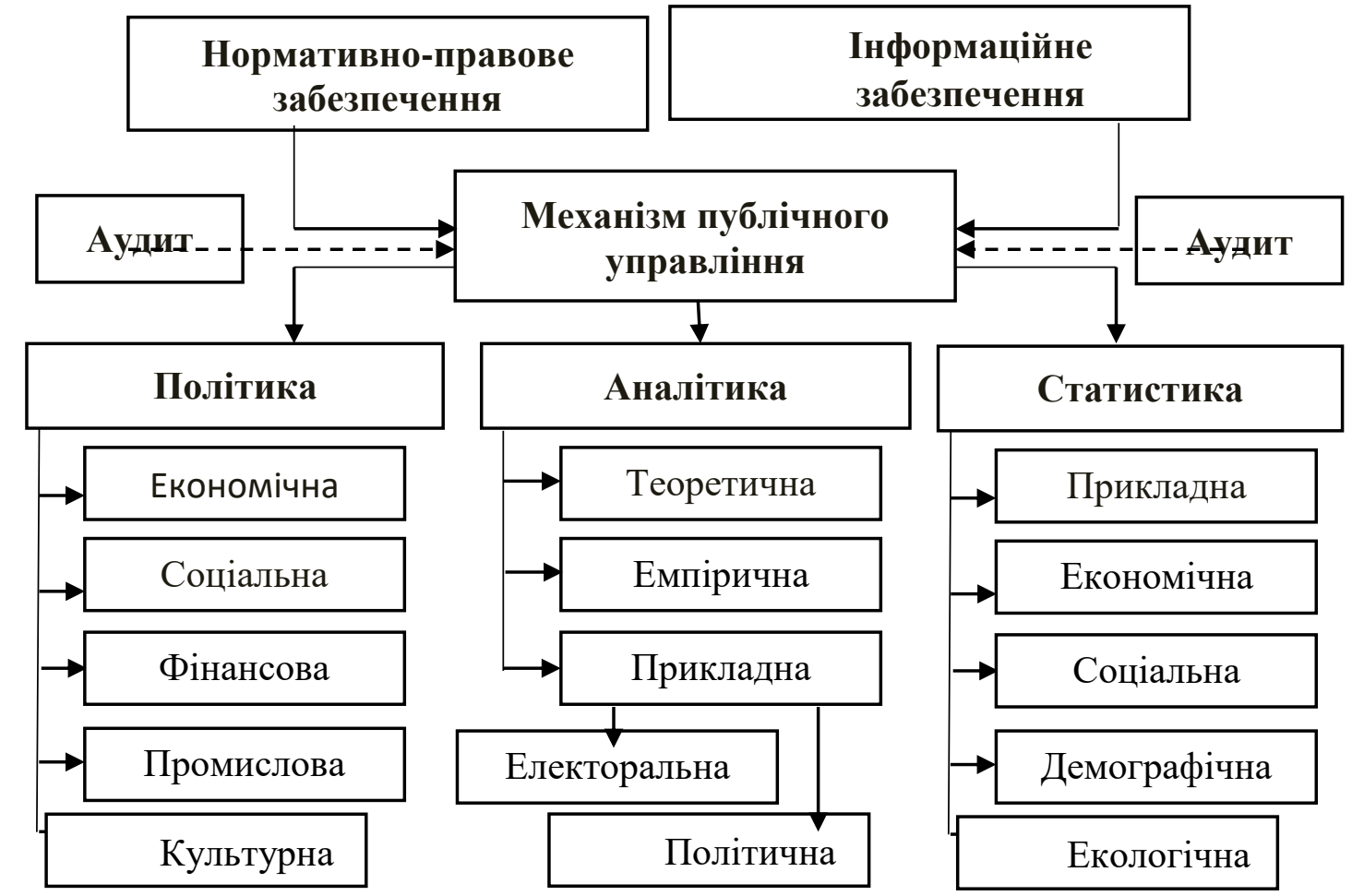

Pис. 1. Структура формування механізму публічного управління Джерело: власні дослідження

Порівняння дозволяє визначити подібність і відмінність предметів і явищ, теорій, точок зору, виявити те спільне, що властиво двом або декільком об'єктам. Так, наприклад, порівняльні дані надходжень доходів загального фонду місцевих бюджетів у 2019-2020 pp. вказують на чітку тенденцію до їх зростання, однак мають сезонно-квартальний характер. В перші місяці досліджуваного періоду, а також в липні, серпні і на кінець аналізованих років спостерігалося різке зростання надходжень доходів до місцевих бюджетів. Натомість у весняний період часу та у вересні-місяці відбувся незначний спад даного показника (рис. 2). 


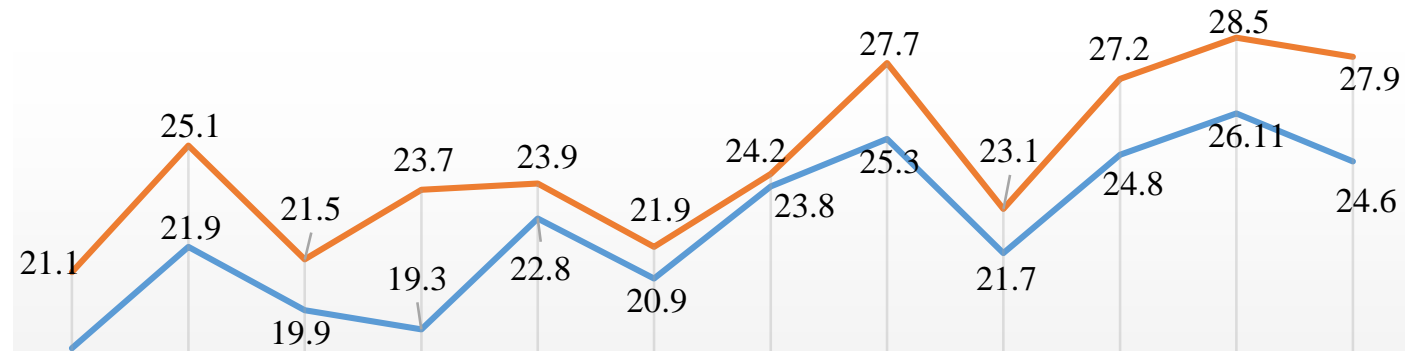

18.7

15

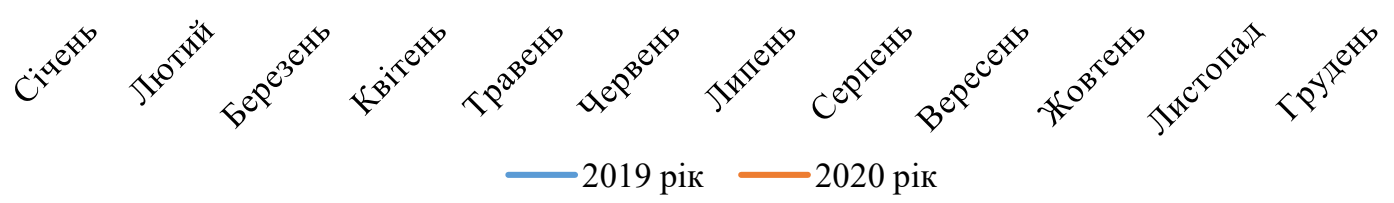

Pис. 3. Порівняльні дані надходжень доходів загального фонду місиевих бюджетів у 2019-2020 рр., млрд. грн

Джерело: [1]

Спостереження вважається найбільш елементарним методом, що виступає, як правило, у якості одного зі складових у комплексі інших емпіричних методів. Можливості метода спостереження обмежені, оскільки він дозволяє виявити лише зовнішні ознаки, зовнішні прояви фактів. Однак, внутрішні процеси залишаються для спостереження недоступними. Саме тому на практиці більше використовують статистичний метод спостереження [3, С. 16].

На думку М. Пугачової, моніторинг також слід розглядати як один із статистичних методів, використання якого дозволяє узагальнити та систематизувати результати досліджень, здійснити контроль та прогнозування у сфері публічного управління [6].

Предметом прикладної політичної аналітики є конкретна суспільно-значуща проблема, насамперед така, що пов'язана $з$ процесами набуття, реалізації та збереження державної влади.

Електоральна політична аналітика спрямовує свої дослідження на задоволення інтересів громадськості до політичного процесу та інтересів політично-активних суб'єктів громадянського суспільства.

Політична аналітика досліджує процеси розроблення та реалізації державновладних рішень, тобто задовольняє потреби, насамперед, суб'єктів державної влади, які несуть відповідальність за ії збереження та примноження. Для інших же зацікавлених сторін аналіз публічної політики висвітлює процес реалізації державної влади та створює можливості для опосередкованої участі в цьому процесі. Політична аналітика, як галузь наукового пізнання, передбачає 
використання певної сукупності методичних прийомів (рис. 2).

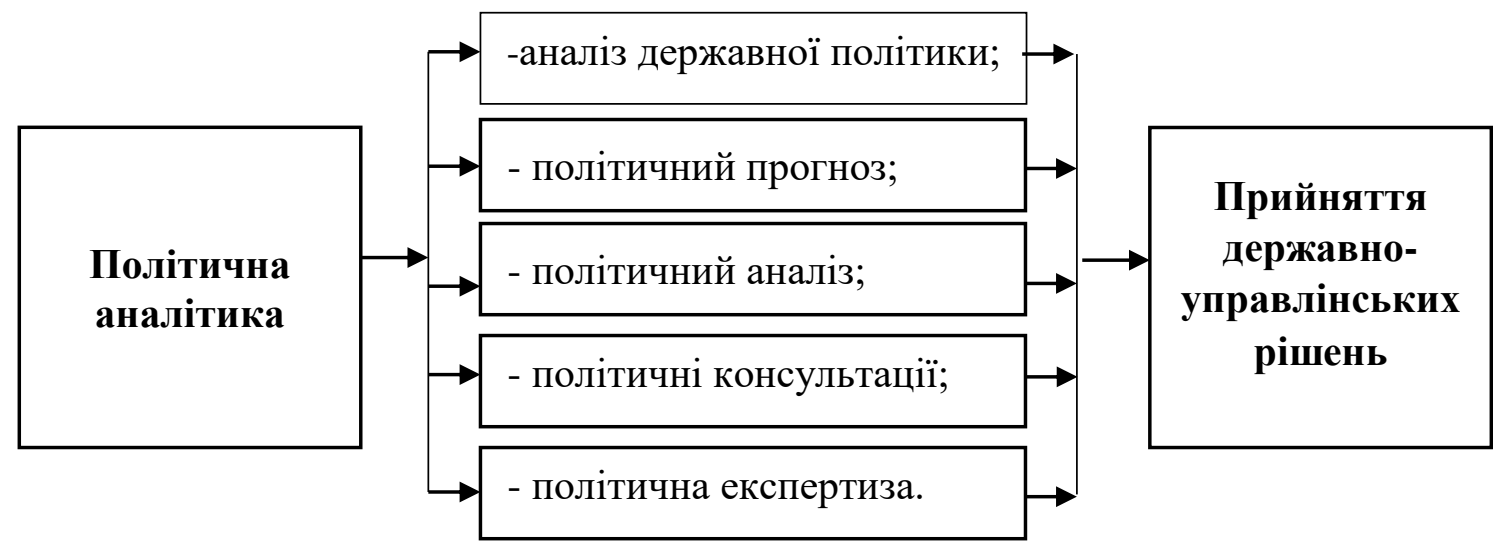

Pис. 2. Механізм впливу політичної аналітики на прийняття державно-

Джерело: власні дослідження

\section{управлінських рімень}

Поряд із аналітичним підходом, виняткове значення для визначення стратегії i тактики розвитку держави, країни, регіонів, органів місцевого самоврядування, видів економічної діяльності, окремих суб'єктів господарювання має статистика. 3 iii допомогою здійснюється зворотний зв’язок, тобто потік інформації йде від об’єкта до суб'єкта управління - керівництва підприємств, об'єднань, територіальних, галузевих і центральних органів влади. Без вірогідної, всебічної і своєчасної інформації прийняття ефективних управлінських рішень неможливе.

3-поміж найбільш вживаних статистико-аналітичних методів, слід виділити наступні: зведення та групування даних, абсолютні та відносні показники, середні величини та показники варіації, ряди динаміки, дисперсійний аналіз, кореляційнорегресійний аналіз, кластерний аналіз тощо. Сукупність вказаних методів притаманна прикладній статистиці, яка в свою чергу дає можливість всебічно охарактеризувати економічну, соціальну, демографічну та екологічну статистики, використовуючи найбільш універсальні аналітичні прийоми. Однак застосовуваність таких інструментів, обмежена тією чи іншою сферою діяльності. Абсолютні показники відіграють важливу роль у системі узагальнюючих статистичних показників публічного управління. Так, наприклад, характеризуючи процес децентралізації в країні, можна зазначити, що у 2019 р. було сформовано 806 ОТГ (у т. ч. 24 ОТГ на основі міст обласного значення); у 2020 р. - 872 ОТГ (у т. ч. 41 ОТГ на основі міст обласного значення) [1]. Система абсолютних показників дозволяє також деталізувати інформацію, зокрема на регіональному рівні: у Житомирській області за 2020 кількість ОТГ становила 66 одиниць, їх площа складала 29664,0 км², населення - 1208212 чоловік. Разом 3 тим такі показники часто не дають достатнього уявлення про досліджуване явище. Відтак 
виникає потреба в обчисленні інших показників, зокрема відносних, які виражають кількісні співвідношення між соціально-економічними явищами.

Такі показники відображаються у 8-ми основних індикаторах, які характеризують фінансові аспекти діяльності об’єднаних територіальних громад:

1. Доходи загального фонду на одного мешканця (співвідношення обсягу надходжень доходів загального фонду без трансфертів до кількості мешканців відповідної ОТГ);

2. Видатки загального фонду на одного мешканця (співвідношення обсягу видатків загального фонду до кількості мешканців відповідної ОТГ);

3. Видатки на утримання апарату управління у розрахунку на одного мешканця (співвідношення обсягу видатків на утримання апарату управління, проведених за рахунок коштів загального фонду, до кількості мешканців відповідної ОТГ);

4. Капітальні видатки на одного мешканця (співвідношення обсягу капітальних видатків бюджету громади до кількості мешканців відповідної ОТГ);

5. Рівень дотаційності бюджетів (співвідношення обсягу базової чи реверсної дотації до загальної суми доходів загального фонду бюджету ОТГ 3 урахуванням базової чи реверсної дотації без урахування субвенцій з державного бюджету);

6. Співвідношення видатків на утримання апарату управління із сумою доходів загального фонду (співвідношення видатків на утримання апарату управління органів місцевого самоврядування із сумою доходів загального фонду без урахування трансфертів з державного бюджету, у відсотках);

7. Питома вага заробітної плати у видатках загального фонду бюджету ОТГ (відсоткова частка проведених із загального фонду бюджету видатків на заробітну плату з нарахуваннями до обсягу видатків загального фонду бюджету без урахування трансфертів, перерахованих з бюджету ОТГ до інших бюджетів);

8. Питома вага капітальних видатків у загальному обсязі видатків (частка капітальних видатків у сумарному обсязі видатків загального та спеціального фонду відповідного бюджету ОТГ) [4].

Виявити закономірності і тенденції розвитку масових явищ у публічному управлінні дозволяють середні величини. Відображаючи основні закономірні, необхідності і властивості окремих досліджуваних сукупностей, середня величина надає узагальнюючу характеристику досліджуваного явища. Так, наприклад, за даними моніторингу процесу децентралізації встановлено, що за 2020 р. до бюджетів 872 ОТГ надійшло 54,0 млрд гривень. Середній обсяг видатків по всіх ОТГ із розрахунку на одного мешканця склав 6986,9 грн., дохід в середньому становив 5200,6 грн [1].

Одним із важливих завдань аналізу публічного сектору економіки є вивчення 
суспільних явищ у безперервному розвитку та динаміці, яке вирішується завдяки побудові й аналізу динамічних (часових) рядів. На практиці досить часто визначають систему абсолютних і відносних показників та середніх величин динаміки. До таких належать: абсолютний приріст, темп (коефіцієнт) зростання, темп приросту, абсолютне значення одного відсотку приросту, середній рівень ряду динаміки, середній абсолютний приріст, середній темп зростання і приросту.

Так, зокрема, за допомогою даного методу можна простежити за динамікою доходів місцевих бюджетів у розрахунку на 1 мешканця в країні (табл. 1).

Таблиияя 1.

Динаміка доходів місцевих бюджетів у розрахунку

на 1 мешканця , грн

\begin{tabular}{|l|c|c|c|}
\hline \multirow{2}{*}{\multicolumn{1}{|c|}{ Назва області }} & \multicolumn{3}{|c|}{ Доходи на 1-го мешканця, грн } \\
\cline { 2 - 4 } & $\mathbf{2 0 1 9} \mathbf{p .}$ & $\mathbf{2 0 2 0} \mathbf{~ . .}$ & $\begin{array}{c}\mathbf{2 0 2 0} \mathbf{~ p . ~} \\
\text { до 2019 p., } \mathbf{~}\end{array}$ \\
\hline Вінницька & 6022,4 & 6409,7 & 106,4 \\
\hline Волинська & 4790,0 & 5140,5 & 107,3 \\
\hline Дніпропетровська & 8971,4 & 9308,9 & 103,8 \\
\hline Донецька & 5386,8 & 5767,9 & 107,1 \\
\hline Житомирська & 5703,2 & 6136,0 & 104,6 \\
\hline Закарпатська & 4067,5 & 4256,2 & 106,6 \\
\hline Запорізька & 7091,8 & 7562,4 & 107,9 \\
\hline Івано-Франківська & 4340,7 & 4681,6 & 108,7 \\
\hline Київська & 8510,3 & 9247,5 & 107,8 \\
\hline Кіровоградська & 6311,3 & 6802,2 & 112,9 \\
\hline Луганська & 3592,8 & 4056,8 & 106,5 \\
\hline Львівська & 6344,5 & 6755,8 & 109,0 \\
\hline Миколаївська & 6122,56 & 670,9 & 105,0 \\
\hline Одеська & 7024,3 & 7378,2 & 101,9 \\
\hline Полтавська & 8469,3 & 8630,7 & 109,5 \\
\hline Рівненська & 4637,4 & 5076,8 & 107,3 \\
\hline Сумська & 6045,8 & 6490,1 & 108,2 \\
\hline Тернопільська & 4402,3 & 4763,1 & 106,0 \\
\hline Харківська & 7038,5 & 7460,5 & 107,9 \\
\hline Херсонська & 4931,8 & 5320,6 & 108,6 \\
\hline Хмельницька & 5492,7 & 5962,8 & 107,3 \\
\hline Черкаська & 6082,4 & 6528,9 & 105,8 \\
\hline Чернівецька & 3796,8 & 4018,6 & 10,4 \\
\hline Чернігівська & 6082,1 & 6713,7 & $\mathbf{1 0 6 , 4}$ \\
\hline м. Київ & 14295,8 & 14963,8 & $\mathbf{7 3 2 7 , 1}$ \\
\hline Україна & $\mathbf{6 ~ 8 8 9 , 5}$ & & \\
\hline
\end{tabular}

\section{Джерело: [1]}

Iз даних таблиці видно, що темп приросту досліджуваного показника, впродовж останніх двох років, найбільше зріс у Чернігівській області - на 10,4\%, найменше - у Полтавській області (2\%). В цілому по Україні зростання 
становило лише $6,4 \%$.

3-поміж найефективніших прийомів обробки масових даних, $\epsilon$ метод зведення і групування, який відкриває широкі можливості для вивчення взаємодії між явищами, виявлення об'єктивних закономірностей досліджуваних процесів, встановлення на певних етапах переходу кількісних змін в якісні. Групуючи досліджувані об'єкти за будь-яким істотним показником i характеризуючи виділені групи за різними показниками, можна простежити залежність між ознакою, покладеною в основу групування і вибраними показниками.

Прикладом зведення та групування є дані таблиці 2, де можна відстежити залежність між середньою сумою видатків на 1 мешканця, найвищого і найнижчого показників видатків та інтервальними розподілами за кількістю населення в ОТГ (табл. 2). Варто зауважити, що у 2020 році із загального фонду бюджетів ОТГ було проведено видатків на суму 72,6 млрд грн., середній обсяг видатків становив 6 986,9 грн. Крім цього, із 872 ОТГ по 353 громадах (40,5\% від загальної кількості) показник видатків на одного мешканця перевищував середній показник по всіх ОТГ .

Таблиия 2.

Аналітичне групування за кількістю населення в ОТГ та видатків із загального фонду на 1-го мешканця

\begin{tabular}{|c|c|c|c|c|c|c|c|}
\hline $\begin{array}{l}\text { № } \\
\text { 3/ח }\end{array}$ & $\begin{array}{l}\text { Інтервали } \\
\text { за } \\
\text { кількістю } \\
\text { населення } \\
\text { в ОТГ, } \\
\text { тис. осіб }\end{array}$ & 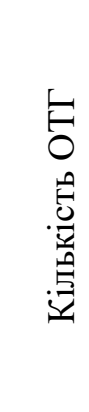 & $\begin{array}{l}\text { Середня } \\
\text { сума } \\
\text { видатків, } \\
\text { проведен } \\
\text { их } 3 \\
\text { бюджету } \\
\text { ОТГ, } \\
\text { млн. грн }\end{array}$ & $\begin{array}{l}\text { Кількість ОТГ, } \\
\text { значення } \\
\text { видатків яких } \\
\text { на } 1 \text { мешканця } \\
\text { є більшим за } \\
\text { середній } \\
\text { показник по } \\
\text { всіх ОТГ } \\
\text { (6986,9 грн) }\end{array}$ & $\begin{array}{l}\text { Середній } \\
\text { показник } \\
\text { видатків на } 1 \\
\text { мешканця, } \\
\text { грн }\end{array}$ & $\begin{array}{l}\text { Найвищий } \\
\text { показник } \\
\text { видатків } \\
\text { на } 1 \\
\text { мешканця, } \\
\text { грн }\end{array}$ & $\begin{array}{l}\text { Найнижчий } \\
\text { показник } \\
\text { видатків на } \\
1 \text { мешканця, } \\
\text { грн }\end{array}$ \\
\hline 1 & понад 15 & 110 & 142,7 & 34 & 6627,7 & 22296,0 & 1931,3 \\
\hline 2 & $\begin{array}{l}\text { від } 10 \text { до } \\
15\end{array}$ & 134 & 83,0 & 50 & 6826,9 & 15084,4 & 3784,5 \\
\hline 3 & $\begin{array}{l}\text { від } 5 \text { до } \\
10\end{array}$ & 277 & 48,4 & 98 & 6894,4 & 21544,3 & 2942,6 \\
\hline 4 & до 5 & 308 & 24,2 & 150 & 7101,8 & 29462,5 & 1313,7 \\
\hline 5 & $\begin{array}{l}\text { ОТГ- } \\
\text { міста } \\
\text { обласного } \\
\text { значення }\end{array}$ & 43 & 578,2 & 21 & 7332,2 & 11884,4 & 44 \\
\hline
\end{tabular}

Джерело: [4] 
Важливими статистико-аналітичними інструментами слід вважати методи стохастичного факторного аналізу до яких належать: дисперсійний, регресійний, кореляційний, кластерний аналіз та методи лінійного програмування. Усі вони направлені на вивчення зв'язків між величинами, при яких числовому значенню однієї з них відповідає декілька значень інших.

Використання комплексу статистико-аналітичних прийомів дозволяє провести якісний внутрішній аналіз діяльності усіх суб'єктів публічного управління. Однак проведення зовнішнього незалежного фахового оцінювання та аналізу результативності й ефективності діяльності органів публічної влади щодо управління функціонуванням публічної сфери (або їі складових) дозволяє аудит. Зважаючи на відносно нову систему реформування органів місцевого самоврядування, аудит є малодослідженою категорією і наразі він перебуває на початкові стадії становлення.

На думку Обушної Н.I., таке поняття слід трактувати як публічний аудит, основна місія якого проявляється у інформуванні суспільства про результати незалежної професійної оцінки діяльності органів публічної влади. Метою публічного аудиту є підвищення прозорості, ефективності та результативності управлінських рішень у публічній сфері, відповідальності та підзвітності органів публічної влади суспільству [8.]. Публічний аудит слід розглядати як суспільний інститут, який, використовуючи сучасні навики професійної діяльності, керуючись принципом науковості та залучаючи громадськість, сприяє підвищенню ефективності і результативності прийняття управлінських рішень (рис. 3).

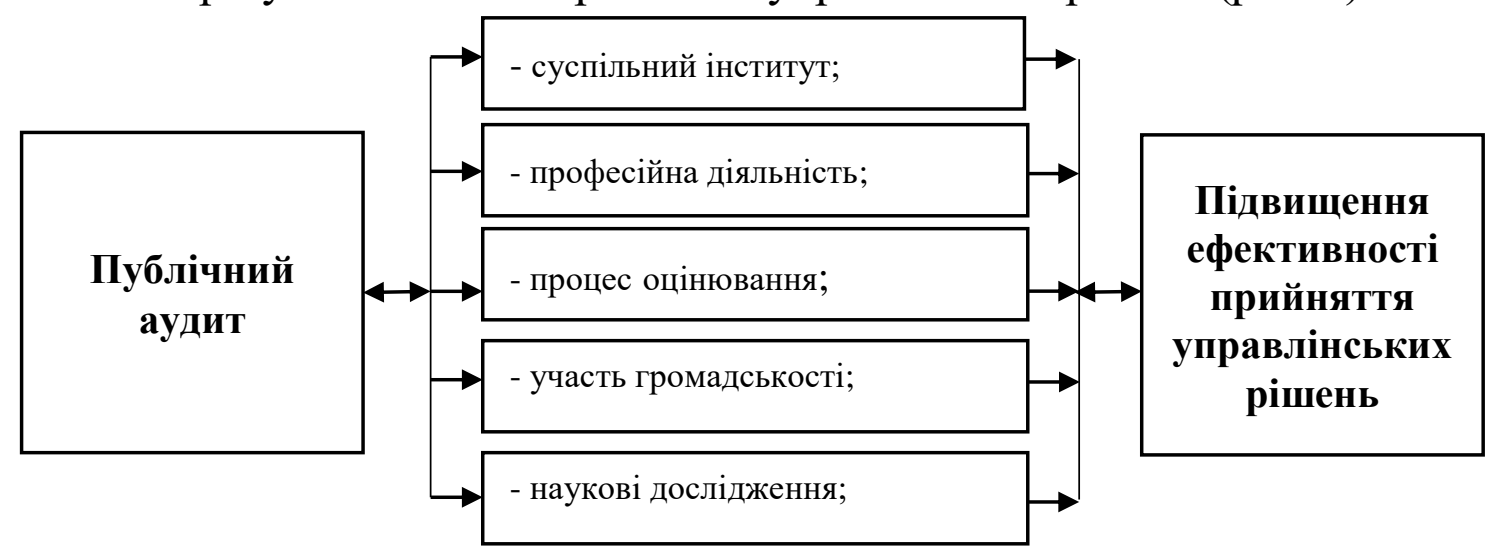

Рис. 3. Роль публічного аудиту в контексті прийняття управлінських рішень Джерело: власні дослідження

Висновки. Використання статистико-аналітичних інструментів та аудиту в публічному управлінні пов'язано, передусім, 3 об’єктивними потребами суспільства мати якомога більше достовірної інформації щодо функціонування різних сфер діяльності - економічної, політичної, соціальної, екологічної тощо. Сукупність різноманітних прийомів і методів моніторингу основних суб'єктів публічного управління здебільшого являють собою складну взаємодію елементів системи. За допомогою абсолютних і відносних величин можна простежити за 
динамікою формування та розвитку ОТГ. Середні величини та їх використання при зведенні та групуванні даних дозволяють визначити взаємозалежність факторних і результативних ознак в генеральній досліджуваній сукупності. Не менш вагомого значення набули прийоми стохастичного факторного аналізу.

Однак завершальним етапом проведення моніторингу i формування основного джерела продукування стратегії модернізації публічного управління має стати публічний аудит. Адже саме публічний аудит, використовуючи статистико-аналітичні інструменти, здатний визначати конфлікти інтересів між суб'єктами публічної сфери, стаючи основним спонукальним фактором для розв’язання проблем і своєчасного прийняття ефективних управлінських рішень.

\section{Лimepamypa:}

1. Аналіз фінансових показників 872 ОТГ у розрізі 24 областей: рейтинг за 2020 рік. URL: https://decentralization.gov.ua/news/13358

2. Андрієнко М., Гаман П. Проблеми та перспективи державного управління України в умовах глобалізації економіки. Науковий вісник: Державне управління. 2021. №1 (7). С. 6-25. https://doi.org/10.32689/2618-0065-2021-1(7)-6-25

3. Грабченко А.І., Федорович В.О., Гаращенко Я.М. Методи наукових досліджень: навч. посібник. Х.: НТУ "ХПІ", 2009. 142 с.

4. 3 якими фінансовими показниками закінчили 2020 рік об'єднані громади рейтинг. URL: https://decentralization.gov.ua/news/13333

5. І Іванова T. В. Публічний аудит як інноваційний механізм модернізації публічного управління. Інвестииії: практика та досвід. 2018. № 8. С. 79-82.

6. Концептуальні основи статистичного моніторингу // За ред. М.В. К.: Інформ. Видво. Центр. Держкомстату України. 2003. 279 с.

7. Мармоза A.T. Економічна статистика: підручник. К.: Центр учбової літератури, 2017. $600 \mathrm{c}$.

8. Обушна H.I. Інституціональні аспекти розвитку публічного аудиту в умовах модернізації публічного управління в Україні: проблеми теорії та практики: монографія. К.: Вид-во «Каравела», 2017. 472 с.

9. Олексенко Р. І., Воронкова В. Г. Формування моделі класифікації соціальних процесів у публічному управлінні та адмініструванні: понятійно-категорійний апарат. Теорія та практика державного управління. 2020. №3(70). C. 82-90. Doi: 10.34213/tp.20.03.09

10. Чальцева О. М. Публічна політика: теоретичний вимір і сучасна практика: монографія. Вінниця : ФОП Барановська Т. П., 2017. 336 с.

\section{References:}

1. Analysis of financial indicators of 872 OTGs in terms of 24 oblasts: rating for 2020 . Retrieved from https://decentralization.gov.ua/news/1335 [in Ukrainian].

2. Andriienko, M. \& Haman P. (2021). Problemy ta perspektyvy derzhavnoho upravlinnia Ukrainy $\mathrm{v}$ umovakh hlobalizatsii ekonomiky [Problems and prospects of public administration of Ukraine in the context of economic globalization]. Naukovyi visnyk: Derzhavne upravlinnia. №1 (7). S. 6-25. https://doi.org/10.32689/2618-0065-2021-1(7)-6-25 [in Ukrainian].

3. Hrabchenko, A. I., Fedorovych, V. O. \& Harashchenko, Ya. M. (2009). Metody 
naukovykh doslidzhen [Research methods]: navch. posibnyk. Kh.: NTU "KhPI", 142 s. [in Ukrainian].

4. With what financial indicators did the united communities end 2020 - rating. Retrieved from https://decentralization.gov.ua/news/13333 [in Ukrainian].

5. Ivanova, T. V. (2018). Publichnyi audyt yak innovatsiinyi mekhanizm modernizatsii publichnoho upravlinnia [Public audit as an innovative mechanism for modernizing public administration]. Investytsii: praktyka ta dosvid № 8. S. 79-82. [in Ukrainian].

6. Kontseptualni osnovy statystychnoho monitorynhu [Conceptual bases of statistical monitoring]. (2003). Za red. M.V. K.: Inform. Vyd-vo. Tsentr. Derzhkomstatu Ukrainy. 279 s. [in Ukrainian].

7. Marmoza, A.T. (2017). Ekonomichna statystyka [Economic statistics]: pidruchnyk. K.: Tsentr uchbovoi literatury. $600 \mathrm{~s}$. [in Ukrainian].

8. Obushna, N.I.(2017). Instytutsionalni aspekty rozvytku publichnoho audytu v umovakh modernizatsii publichnoho upravlinnia v Ukraini: problemy teorii ta praktyky [Institutional aspects of public audit development in the conditions of public administration modernization in Ukraine: problems of theory and practice]: monohrafiia. K.: Vyd-vo «Karavela». $472 \mathrm{~s}$. [in Ukrainian].

9. Oleksenko ,R. I. \& Voronkova, V. H.(2020). Formuvannia modeli klasyfikatsii sotsialnykh protsesiv u publichnomu upravlinni ta administruvanni: poniatiino-katehoriinyi aparat [Formation of a model of classification of social processes in public administration and administration: conceptual and categorical apparatus]. Teoriia ta praktyka derzhavnoho upravlinnia. №3(70). S. 8290. Doi: 10.34213/tp.20.03.09. [in Ukrainian].

10. Chaltseva, O. M. (2017). Publichna polityka: teoretychnyi vymir i suchasna praktyka [Public policy: theoretical dimension and modern practice]: monohrafiia: Vinnytsia: FOP Baranovska T. P..336 s. [in Ukrainian]. 